\title{
MECHANISMS AFFECTING PEPLOMYCIN SENSITIVITY OF CHINESE HAMSTER CELL LINES
}

\author{
Shogo Ozawa, Akiteru Tamura, Hideo Suzuki, Toshio Nishimura \\ and NoBUo TANAKA \\ Institute of Applied Microbiology, University of Tokyo, \\ Tokyo 113, Japan
}

(Received for publication May 10, 1985)

\begin{abstract}
Chinese hamster lung cell line V79 was $c a .13$ times more resistant to peplomycin (PEP), and 6 times more resistant to bleomycin (BLM)- $\mathrm{A}_{2}$ than Chinese hamster ovary (CHO) cell line. The natural resistance of V79 cells to PEP or BLM was attributed to higher levels of BLM hydrolase activity and lower cellular uptake of the antibiotic. The sensitivity to PEP of a mutant clone $\mathrm{CHO} / \mathrm{O}-2 \mathrm{~T}-1$ was similar to that of $\mathrm{CHO}$. A hybrid clone of $\mathrm{CHO} / \mathrm{O}-2 \mathrm{~T}-1 \times$ V79 showed an intermediate sensitivity to PEP between those of both parental cell lines, suggesting that the gene responsible for the natural resistance to PEP appears codominantly in the hybrid. The BLM hydrolase activity of the hybrid was also found intermediate between those of both parental cells.

Mutant clones $\mathrm{CHO} / \mathrm{O}-2 \mathrm{~T}-5$ and $\mathrm{CHO} / \mathrm{O}-2 \mathrm{~T}-6$ were $8.3 \sim 9.0$ times more sensitive to PEP than CHO cells. Hybrid clones CHO/O-2 T-5 $\times$ V79 and CHO/O-2 T- $6 \times$ V79 displayed PEP sensitivity similar to that of V79, suggesting that the gene responsible for the PEP supersensitivity (PEPSS) behaves recessively in the hybrids. Both PEPss clones showed levels of BLM hydrolase and cellular uptake of $\left[{ }^{3} \mathrm{H}\right] \mathrm{PEP}$ similar to the parental $\mathrm{CHO}$ cells, suggesting that the PEPSS is due to neither BLM hydrolase nor cellular uptake of the antibiotic. Increased PEP-induced DNA cleavage and decreased DNA repair in the PEPSS clones were demonstrated by alkaline sucrose density gradient sedimentation method. The results suggest that the PEPSs of these mutant clones is attributed to decreased DNA-repairing activity and/or increased DNA-breaking activity.
\end{abstract}

Bleomycin (BLM) is widely used in the treatment of human squamous cell carcinomas, testicular carcinoma, and malignant lymphoma. The antibiotic is less effective for adenocarcinomas and sarcomas. The diverse sensitivity to BLM of various tumors is attributed to the drug uptake and BLM hydrolase activity $\left(c f\right.$. a monograph $\left.{ }^{1)}\right)$. However, the detailed mechanism of BLM sensitivity of various tumors still remains open to discussion.

MIYAKI et al. ${ }^{2)}$ reported that BLM-resistant rat ascites hepatoma cells show higher BLM hydrolase activity than BLM-sensitive hepatoma cells. AKIYAMA and $\mathrm{KUWANO}^{4)}$ isolated BLM-resistant mutants of Chinese hamster ovary (CHO) cells, due to high BLM hydrolase activity. We obtained BLMresistant cell lines of murine lymphoma L5178Y, in which the resistance is attributed to alteration of the plasma membrane transport system ${ }^{3)}$.

We have studied the mechanism of action of $\mathrm{BLM}^{5,6)}$, and are interested in the mechanism of BLM resistance of tumor cells ${ }^{3)}$. In the current studies, we mainly used peplomycin (PEP), an antibiotic of the BLM group, which contain [3-((S)-1-phenylethyl)aminopropyl]amino group ${ }^{12)}$. We have found that Chinese hamster lung fibroblast-like cell line V79 is more resistant to PEP than CHO, and have also isolated PEP-supersensitive (PEPSs) mutants of CHO cells. We have further studied these mechanisms as models of a variety of PEP or BLM sensitivity of human neoplasms ${ }^{1)}$. The results are presented in this publication. 


\section{Materials and Methods}

PEP and $\left[{ }^{3} \mathrm{H}\right] \mathrm{PEP}$ (phenyl $-\mathrm{m}^{3} \mathrm{H}, 250 \mu \mathrm{Ci} / \mathrm{mg}$ ) ${ }^{7}$ were kindly provided by Nippon Kayaku Co., Ltd., Tokyo, Japan.

\section{Cells and Culture Conditions}

$\mathrm{CHO}$ and V79 cell lines were generously given by Prof. S. OKADA, School of Medicine, University of Tokyo. The cells were cultured in McCoy $5 \mathrm{~A}$ medium supplemented with $10 \%$ calf serum and $5 \%$ fetal calf serum at $37^{\circ} \mathrm{C}$ in atmosphere of $5 \% \mathrm{CO}_{2}$ and $95 \%$ air.

\section{Drug Sensitivity}

The drug sensitivity was expressed by $\mathrm{IC}_{00}$ : i.e. drug concentrations reducing relative plating efficiency of a cell line to $10 \%$ of that obtained in the absence of drugs. Plating efficiency was determined by plating 200 cells in a well of 6-well plastic plates. After 6 to 8 days of incubation at $37^{\circ} \mathrm{C}$, the plates were stained by $0.1 \%$ crystal violet, and colonies were scored. The relative plating efficiency was calculated as the ratio of the colony number at a given drug concentration to that obtained in the absence of drugs.

\section{Bleomycin Hydrolase}

Bleomycin hydrolase activity was determined, using HPLC $^{8)}$ and bioassay, using Bacillus subtilis ATCC 6633 as a test organism ${ }^{4}$. Cells were homogenized with $1 / 15 \mathrm{M}$ phosphate buffer (pH 7.2) in a Teflon homogenizer, and centrifuged at $105,000 \times g$ for 60 minutes. The supernatant was used as an enzyme solution, which $(0.45 \mathrm{ml})$ was added to $0.05 \mathrm{ml}$ of $8 \mathrm{mg} \mathrm{PEP} / \mathrm{ml}$ solution, and incubated for 2 hours at $37^{\circ} \mathrm{C}$. The reaction was terminated by addition of $0.5 \mathrm{ml}$ of $\mathrm{MeOH}$. The reaction mixture was centrifuged at 3,000 rpm for 10 minutes, and the supernatant was bioassayed by a paper disc method. For HPLC, $2 \mathrm{mg}$ of cupric carbonate was added to the supernatant, and $20 \mu \mathrm{l}$ of each sample was injected into HPLC column. HPLC conditions; Column, $4.6 \times 250 \mathrm{~mm}$, Senshu pak Aquasil SS-352N, particle size $5 \mu \mathrm{m}$ (Senshu Scientific Co., Ltd., Tokyo). Mobile phase, $\mathrm{MeOH}$ acetonitrile - 20\% ammonium acetate - AcOH, 620: 380: 100: 0.5.

\section{Cellular Uptake of $\left.\left[{ }^{3} \mathrm{H}\right] \mathrm{PEP}{ }^{9}\right)$}

Cells, harvested by trypsinization $\left(10^{7} / \mathrm{ml}\right)$, were incubated in the culture medium with $\left[{ }^{3} \mathrm{H}\right] \mathrm{PEP}$ $(1.02 \mu \mathrm{g} / \mathrm{ml})$ at $37^{\circ} \mathrm{C}$ for various periods. The uptake was terminated by rapid sedimentation, using an Eppendorf centrifuge 5412. $1.0 \mathrm{ml}$ of cell suspension was added on $200 \mu \mathrm{l}$ of an oil mixture, consisting of 80 parts of silicone oil SH500 and 20 parts of liquid paraffin. The mixture was sedimented at 15,000 rpm for 30 seconds. The cell pellet was solubilized with $0.5 \mathrm{ml}$ of Protosol (New England Nuclear) by incubation overnight at $37^{\circ} \mathrm{C}$. The radioactivity was determined in a liquid scintillation spectrometer, using scintillation fluid Dimilume-30 (United Technologies Packard).

\section{Efflux of $\left[{ }^{3} \mathrm{H}\right] \mathrm{PEP}$}

The efflux of $\left[{ }^{3} \mathrm{H}\right] \mathrm{PEP}$ from cells was examined, following the method previously described ${ }^{10)}$. Cells $\left(10^{8} / \mathrm{ml}\right)$ were incubated with $\left[{ }^{3} \mathrm{H}\right] \mathrm{PEP}(0.24 \mu \mathrm{g} / \mathrm{ml})$ for 30 minutes at $37^{\circ} \mathrm{C}$ in the culture medium. Then a part of the cells was sedimented for determining the radioactivity incorporated as described above. The residual cells were washed 3 times by centrifugation, resuspended in the fresh medium $\left(10^{\circ} / \mathrm{ml}\right)$, and incubated for 30 minutes at $37^{\circ} \mathrm{C}$. The radioactivity remaining in the cells, before and after incubation, was analyzed as described above.

\section{Isolation of Ouabain- and 6-Thioguanine-resistant Clones}

The parental $\mathrm{CHO}$ cells were treated with $N$-methyl- $N$ '-nitro- $N$-nitrosoguanidine (MNNG) $(0.5 \mu \mathrm{g} / \mathrm{ml})$ for 3 hours at $37^{\circ} \mathrm{C}$ in the culture medium, and further incubated in MNNG-free medium for 3 days at $37^{\circ} \mathrm{C}$. Then several ouabain-resistant clones were selected by $1 \mathrm{~mm}$ ouabain, and then treated with MNNG in a similar way to obtain ouabain- and 6-thioguanine-resistant clones.

\section{Cell Hybridization}

Hybrid cells of V79 and CHO were constructed as described previously ${ }^{11)}$. V79 cells of $3 \times 10^{6}$ were mixed with the same number of $\mathrm{CHO}$ cells, and treated with $50 \%$ polyethylene glycol 4000 in 
Table 1. Sensitivity of $\mathrm{CHO}$ and V79 cell lines to various antitumor agents.

\begin{tabular}{llllc}
\hline \multirow{2}{*}{\multicolumn{1}{c}{ Agent }} & \multicolumn{2}{c}{$\mathrm{IC}_{90}(\mu \mathrm{g} / \mathrm{ml})$ of } & & $\begin{array}{c}\text { Ratio of } \\
\mathrm{IC}_{90}\end{array}$ \\
\cline { 2 - 3 } \cline { 5 - 5 } & $\mathrm{V} 79$ & $\mathrm{CHO}$ & & $\mathrm{V} 79 / \mathrm{CHO}$ \\
\hline Peplomycin & 1.9 & 0.15 & & 13 \\
Bleomycin $\mathrm{A}_{2}$ & 2.7 & 0.48 & & 5.5 \\
Aclarubicin & 0.030 & 0.029 & & 1.0 \\
Doxorubicin & 0.080 & 0.13 & & 0.62 \\
Mitomycin C & 0.014 & 0.016 & & 0.85 \\
Actinomycin D & 0.0013 & 0.0023 & & 0.57 \\
Neothramycin & 0.063 & 0.13 & & 0.50 \\
Arabinosylcytosine & 0.033 & 0.11 & & 0.31 \\
\hline
\end{tabular}

Table 2. BLM hydrolase activity of V79 and CHO cell lines.

\begin{tabular}{|c|c|c|c|}
\hline & Cell line & Cell extract & BLM hydrolase \\
\hline \multirow{2}{*}{\multicolumn{2}{|c|}{ V79 }} & $0.5^{*}$ & $4.1^{* *}$ \\
\hline & & 1.0 & 3.6 \\
\hline \multirow{2}{*}{\multicolumn{2}{|c|}{$\mathrm{CHO}$}} & 0.5 & 1.8 \\
\hline & & 1.0 & 1.7 \\
\hline \multicolumn{4}{|c|}{ mg protein $/ \mathrm{ml}$. } \\
\hline$* *$ & \multicolumn{3}{|c|}{$\begin{array}{l}\text { Specific activity ( } \mu \mathrm{g} \text { PEP hydrolyzed/mg } \\
\text { protein/minute). }\end{array}$} \\
\hline
\end{tabular}

serum-free McCoy $5 \mathrm{~A}$ medium for 1 minute at $37^{\circ} \mathrm{C}$. The cells were then washed and incubated in the same medium supplemented with $10 \%$ calf serum, $5 \%$ fetal calf serum, $100 \mu \mathrm{M}$ hypoxanthine, $0.4 \mu \mathrm{m}$ aminopterin, $16 \mu \mathrm{m}$ thymidine and $1 \mathrm{~mm}$ ouabain (selection medium). Usually several hybrid cells were obtained out of $10^{5}$ parental cells.

\section{Chromosome Number}

The chromosome number was determined in 100 individual metaphase spreads by the ordinary method. The cells $\left(1 \sim 2 \times 10^{6}\right)$ were cultured in $10 \mathrm{ml}$ of the culture medium with $0.2 \mu \mathrm{g}$ Colcemid/ml for 2 hours at $37^{\circ} \mathrm{C}$ in a dish of $100 \mathrm{~mm}$ diameter. The cells were trypsinized, lysed in a hypotonic $\mathrm{KCl}$, fixed in acetic methanol, and stained with Giemsa solution.

\section{Alkaline Sucrose Gradient Sedimentation Analysis of DNA Strand Scission In Vivo}

DNA breakage in the intact cells treated with PEP was examined, following the procedure described previously ${ }^{13)}$. In each plate, the cells $\left(c a .10^{8}\right)$ were incubated with $0.5 \mu \mathrm{Ci}$ of $\left[{ }^{3} \mathrm{H}\right]$ thymidine for 16 hours, washed, and then incubated with various concentrations of PEP for an hour at $37^{\circ} \mathrm{C}$ in the culture medium described above. The cells were harvested by trypsinization $\left(\mathrm{ca} .10^{5} / 0.2 \mathrm{ml}\right)$ and gently applied on the top of $5 \sim 20 \%$ (w/v) alkaline sucrose gradient in $4.2 \mathrm{ml}$ of $0.3 \mathrm{M} \mathrm{NaOH}, 0.7 \mathrm{M}$ $\mathrm{NaCl}$ and $0.01 \mathrm{M}$ EDTA, on which $0.2 \mathrm{ml}$ of lysis solution $(0.5 \mathrm{M} \mathrm{NaOH}, 0.02 \mathrm{M}$ EDTA and $0.1 \%$ Triton X) had been layered. After standing at room temperature for 10 hours, centrifugation was carried out in a Beckman SW 50L rotor at $30,000 \mathrm{rpm}$ for 90 minutes at $20^{\circ} \mathrm{C}$. Samples were fractionated in $0.3 \mathrm{ml}$ from the top of the gradient with an ISCO fractionator, Model 640. Each fraction was precipitated, after addition of $100 \mu \mathrm{g}$ of bovine serum albumin as a carrier, by cold $5 \% \mathrm{TCA}$ and the radioactivity was determined in a liquid scintillation counter.

\section{Alkaline Sucrose Gradient Centrifugation Analysis of Repair of DNA Damage}

The cells, labeled with $\left[{ }^{3} \mathrm{H}\right]$ thymidine as described above, were incubated in the culture medium with PEP $(100 \mu \mathrm{g} / \mathrm{ml})$ for 2.5 hours, and then in the PEP-free medium for various periods at $37^{\circ} \mathrm{C}$. The size of DNA was analyzed by alkaline sucrose density gradient sedimentation as described above, except that fractions in $0.2 \mathrm{ml}$ were collected.

\section{Results}

\section{Drug Sensitivity of V79 and CHO Cell Lines}

The drug sensitivity of V79 cells to various antitumor drugs was compared with that of CHO cells. The $\mathrm{IC}_{90}$ values, which reduce relative plating efficiency of the cells to $10 \%$ of control, are presented in Table 1. V79 cells were approximately 13 times more resistant to PEP and 6 times to BLM- $\mathrm{A}_{2}$ than $\mathrm{CHO}$ cells. On the contrary, both cell lines showed equal sensitivity to aclarubicin, and V79 cells were a little more sensitive to doxorubicin, mitomycin C, actinomycin D, neothramycin 
Fig. 1. Cellular uptake of $\left.{ }^{3} \mathrm{H}\right] \mathrm{PEP}$ by $\mathrm{CHO}(\bullet)$ and V79 (O) cells.

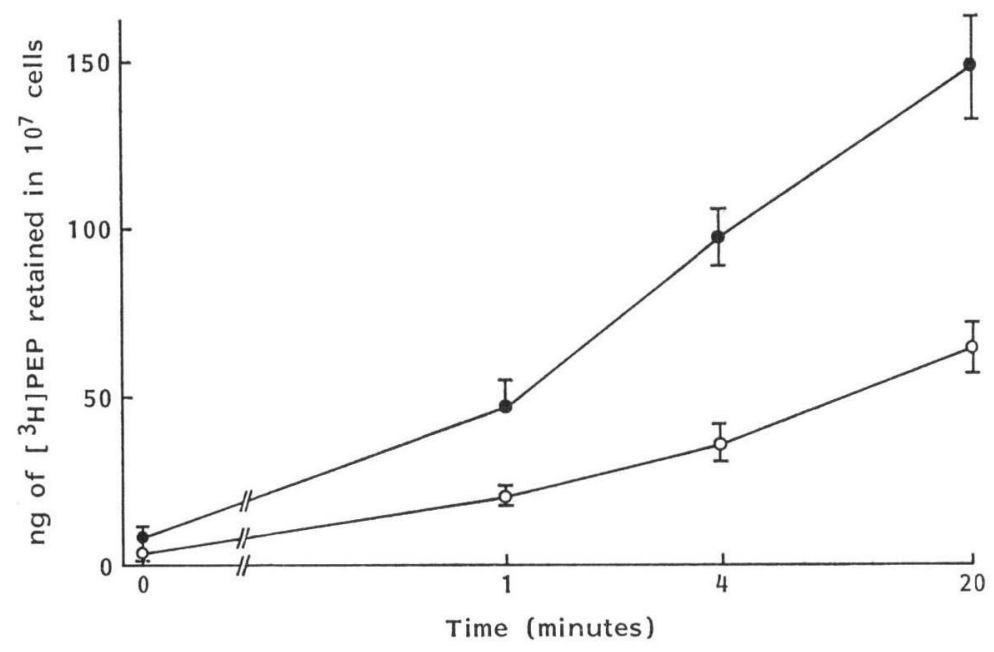

or arabinosylcytosine than CHO cells. The results suggest that the natural resistance of V79 cells is limited to the bleomycin group of antibiotics.

\section{BLM Hydrolase Activity of V79 and CHO Cells}

For the purpose of elucidating the mechanism of BLM resistance of V79 cells, BLM hydrolase activity of cell extracts ( 0.5 or $1.0 \mathrm{mg}$ protein $/ \mathrm{ml}$ ) was studied by HPLC and bioassay, using PEP as a substrate. The results obtained by HPLC method are presented in Table 2, and are in accordance with those by bioassay (Table 4). V79 cells displayed 2.1 2.3 times higher BLM hydrolase activity than CHO cells. The results suggest that BLM resistance of V79 cells is partially due to higher BLM hydrolase activity.

\section{Cellular Uptake and Efflux of $\left[{ }^{3} \mathrm{H}\right] \mathrm{PEP}$}

The time course of $\left[{ }^{3} \mathrm{H}\right] \mathrm{PEP}$ uptake by V79 or $\mathrm{CHO}$ cells was studied in connection with the mechanism of BLM resistance of V79 cells, and the results are illustrated in Fig. 1. Cellular uptake of $\left[{ }^{3} \mathrm{H}\right] \mathrm{PEP}$ for 20 minutes was $148 \mathrm{ng} / 10^{7} \mathrm{CHO}$ cells, and $64.8 \mathrm{ng} / 10^{7} \mathrm{~V} 79$ cells. The former was 2.3 times higher than the latter.

Efflux of $\left[{ }^{3} \mathrm{H}\right] \mathrm{PEP}$ from V79 or CHO cells occurred at the same rate (Fig. 2). [ $\left.{ }^{3} \mathrm{H}\right] \mathrm{PEP}$ retained in $10^{8} \mathrm{CHO}$ cells after 30 minutes reincubation in the fresh medium was $11.8 \mathrm{ng}$, and that in $10^{6} \mathrm{~V} 79$ cells $5.28 \mathrm{ng}$. The retention of PEP in CHO cells was 2.2 times higher than that in V79 cells.

The results suggest that BLM resistance of V79 cells may also be attributed to decreased uptake and retention of PEP.

\section{Sensitivity to PEP of Ouabain-Thioguanine-Resistant CHO Sublines and their Hybrid Cells with V79}

$\mathrm{CHO}$ cell sublines resistant to ouabain and 6-thioguanine were established, for the purpose of constructing $\mathrm{CHO} \times \mathrm{V} 79$ hybrid clones. As presented in Table 3, the $\mathrm{IC}_{80}$ values of PEP were 0.14 $\mu \mathrm{g} / \mathrm{ml}$ for parental $\mathrm{CHO}$ cells and $0.21 \mu \mathrm{g} / \mathrm{ml}$ for CHO/O-2 T-1 cells. Both cell lines showed a similar sensitivity to PEP. V79 cells were more resistant to PEP; the $\mathrm{IC}_{90}$ was $1.2 \mu \mathrm{g} / \mathrm{ml}$. 
Table 3. Sensitivity to PEP of ouabain-thioguanine-resistant $\mathrm{CHO}$ sublines and their hybrids with V79 cells.

\begin{tabular}{|c|c|c|c|c|}
\hline Cell line & $\begin{array}{c}\text { Chromosome } \\
\text { number }\end{array}$ & $\begin{array}{c}\text { Sensitivity } \\
\text { IC }_{80}(\end{array}$ & $\begin{array}{l}\text { to PEP } \\
\mu \mathrm{g} / \mathrm{ml})\end{array}$ & Gene \\
\hline $\mathrm{CHO}$ & 21 & 0.14 & $(\mathrm{~S})^{*}$ & \\
\hline $\mathrm{CHO} / \mathrm{O}-2 \mathrm{~T}-1$ & 21 & 0.21 & (S) & \\
\hline V79 & 22 & 1.2 & (R) & \\
\hline Hybrid (O-2 T-1 ×V79) & 43 & 0.81 & & Codominant \\
\hline $\mathrm{CHO} / \mathrm{O}-2 \mathrm{~T}-5$ & 21 & 0.017 & (SS) & \\
\hline $\mathrm{CHO} / \mathrm{O}-2 \mathrm{~T}-6$ & 21 & 0.015 & (SS) & \\
\hline Hybrid (O-2 T-5 × V79) & 46 & 1.1 & $(\mathrm{R})$ & Recessive \\
\hline Hybrid (O-2 T-6 × V79) & 44 & 0.81 & $(\mathrm{R})$ & Recessive \\
\hline
\end{tabular}

* Sensitivity to PEP: S; PEP-sensitive, R; PEP-resistant, SS; PEP-supersensitive.

Fig. 2. Efflux of $\left[{ }^{3} \mathrm{H}\right] \mathrm{PEP}$ from $\mathrm{CHO}($ ) and V79 (○) cells.

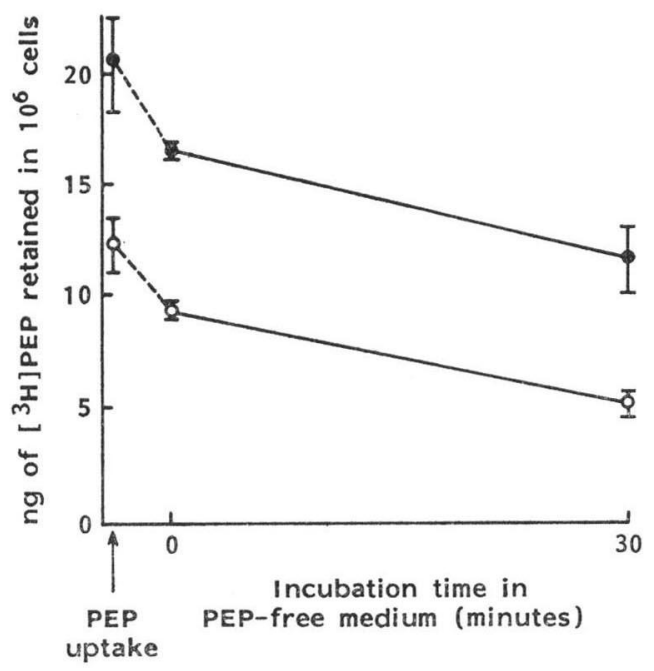

Table 4. BLM hydrolase activity of the hybrid of CHO/O-2 T-1 and V79 cells.

\begin{tabular}{lc}
\hline \multicolumn{1}{c}{ Cell line } & BLM hydrolase \\
\hline V79 & $3.7^{*}$ \\
CHO/O-2 T-1 & 1.7 \\
Hybrid (V79 $\times$ CHO/O-2 T-1) & 2.3 \\
\hline
\end{tabular}

* Specific activity ( $\mu \mathrm{g}$ PEP hydrolyzed/mg protein/minute).

BLM hydrolase was determined by bioassay. The cell extract used was $1.0 \mathrm{mg}$ protein $/ \mathrm{ml}$.

The $\mathrm{IC}_{90}$ value of PEP for $\mathrm{CHO} / \mathrm{O}-2 \mathrm{~T}-1 \times$ V79 hybrid clone was $0.81 \mu \mathrm{g} / \mathrm{ml}$, which was intermediate between those for $\mathrm{CHO} / \mathrm{O}-2 \mathrm{~T}-1$ and V79 cells (Table 3). The dose-response curve of O-2 T- $1 \times$ V79 hybrid clone for PEP was located between those of $\mathrm{CHO} / \mathrm{O}-2 \mathrm{~T}-1$ and V79 cells (data are not shown). The results suggest

that the gene, responsible for natural resistance to PEP, appears codominantly in the hybrid cells.

The BLM hydrolase activity of the hybrid was found intermediate between those of parental cell lines (Table 4). The result is in accord with the above assumption.

The CHO/O-2 T-5 and CHO/O-2 T-6 sublines were 8.3 9.0 times more sensitive to PEP than the parental cells: i.e. $\mathrm{IC}_{90}$ were $0.017 \sim 0.015 \mu \mathrm{g} / \mathrm{ml}$ (Table 3).

The CHO/O-2 T-5 $\times$ V79 and CHO/O-2 T-6 $\times$ V79 hybrid clones displayed $\mathrm{IC}_{20}$ of $1.1 \sim 0.81 \mu \mathrm{g} /$ $\mathrm{ml}$, which were similar to $\mathrm{IC}_{80}$ for $\mathrm{V} 79$ cells, suggesting that the gene responsible for PEPSS phenotype behaves recessively in the hybrid cells.

All the hybrid clones, described above, showed chromosome numbers nearly additive for the parental cell lines before cell-to-cell fusion (Table 3).

\section{Sensitivity of PEPSs Cells to Various Drugs}

The sensitivity of $\mathrm{CHO} / \mathrm{O}-2 \mathrm{~T}-6$ ( PEPSS $^{\mathrm{SS}}$ cells) to various agents was compared with that of the parental $\mathrm{CHO}$ cells, in order to examined whether $\mathrm{CHO} / \mathrm{O}-2 \mathrm{~T}-6$ cells exhibited supersensitivity to 
Table 5. Comparison of drug sensitivity of $\mathrm{CHO}$ and its mutant $\mathrm{O}-2 \mathrm{~T}-6 . \quad \mathrm{IC}_{90}(\mu \mathrm{g} / \mathrm{ml})$ values.

\begin{tabular}{llc}
\hline \multirow{2}{*}{\multicolumn{1}{c}{ Agent }} & \multicolumn{2}{c}{ Cell line } \\
\cline { 2 - 3 } & \multicolumn{1}{c}{ CHO } & CHO/O-2 T-6 \\
\hline Peplomycin & 0.14 & 0.015 \\
Actinomycin D & 0.0040 & 0.0040 \\
Mitomycin C & 0.020 & 0.020 \\
Aclarubicin & 0.060 & 0.050 \\
Doxorubicin & 0.096 & 0.094 \\
Neothramycin & 0.20 & 0.20 \\
Arabinosylcytosine & 0.15 & 0.15 \\
4-Nitroquinoline oxide & 1.8 & 0.96 \\
\hline
\end{tabular}

Table 6. BLM hydrolase activity of cell extracts of parental and PEP-supersensitive cell lines of CHO.

\begin{tabular}{|c|c|}
\hline Cell line & BLM hydrolase \\
\hline $\mathrm{CHO}$ & $0.61^{*}$ \\
\hline $\mathrm{CHO} / \mathrm{O}-2 \mathrm{~T}-5$ & 0.60 \\
\hline $\mathrm{CHO} / \mathrm{O}-2 \mathrm{~T}-6$ & 0.81 \\
\hline
\end{tabular}

* Specific activity ( $\mu \mathrm{g}$ PEP hydrolyzed/mg protein/minute).

The cell extract used was $3.0 \mathrm{mg}$ protein $/ \mathrm{ml}$.

Fig. 3. Cellular uptake of $\left[{ }^{3} \mathrm{H}\right] \mathrm{PEP}$ by $\mathrm{CHO}$ and $\mathrm{CHO} / \mathrm{O}-2 \mathrm{~T}-6(\mathrm{O})$ cells.

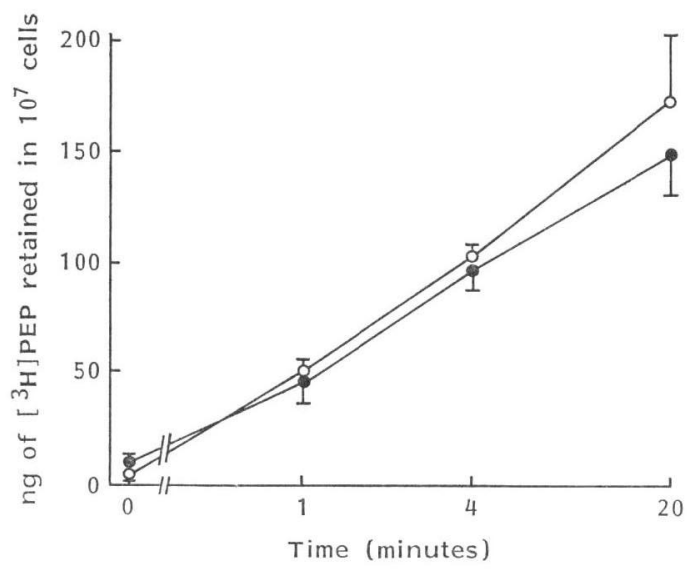

Fig. 4. DNA strand scission induced by PEP in CHO (A) and CHO/O-2 T-6 (B) cells: Sedimentation profiles.

$\bigcirc 50 \mu \mathrm{g} \mathrm{PEP} / \mathrm{ml}, \triangle 25 \mu \mathrm{g} \mathrm{PEP} / \mathrm{ml}, 00$.

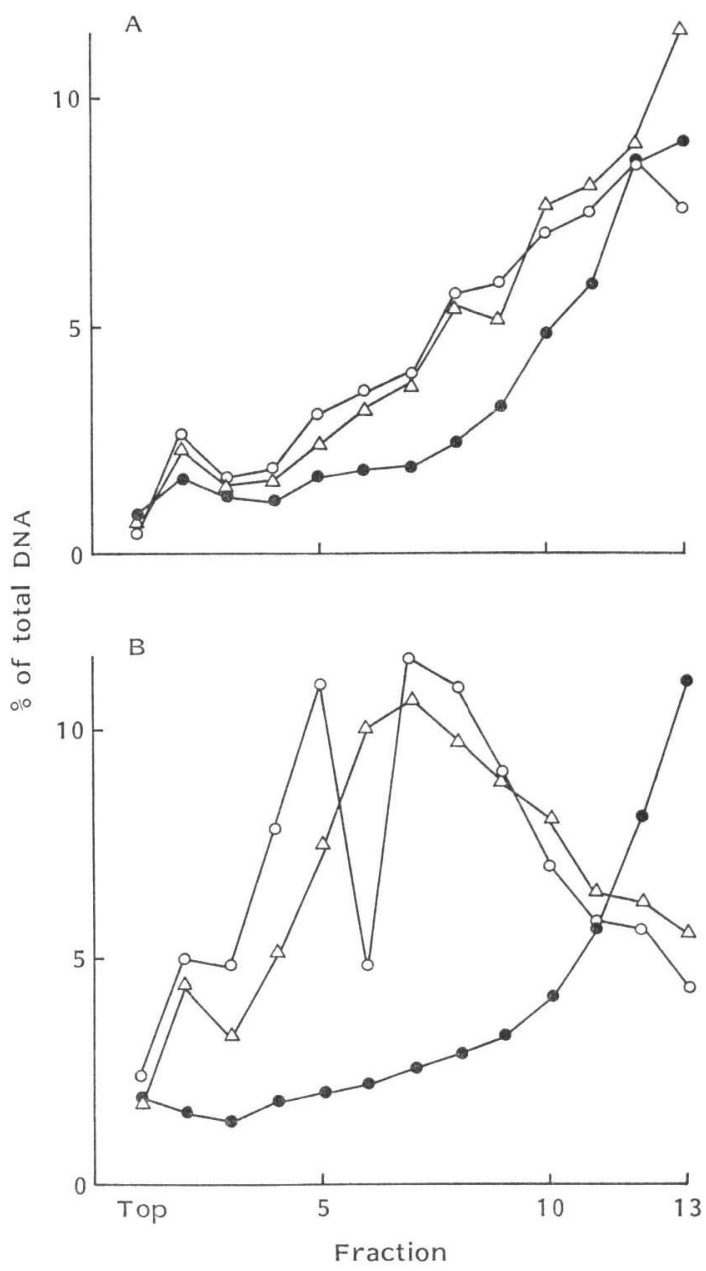

other drugs. The results are summarized in Table 5. Both cell lines displayed similar sensitivity to actinomycin D, mitomycin C, aclarubicin, doxorubicin, neothramycin, and arabinosylcytosine. $\mathrm{CHO} / \mathrm{O}-2 \mathrm{~T}-6$ cells were 1.9 times more sensitive to 4-nitroquinoline oxide than the parental cells, but the difference of sensitivity was not so remarkable as that to $\mathrm{PEP}$. The results indicate that the drug hypersensitivity of $\mathrm{CHO} / \mathrm{O}-2 \mathrm{~T}-6$ cells is limited to PEP and BLM.

\section{BLM Hydrolase Activity of PEPss Clones}

For the purpose of elucidating the mechanism of PEPSS of CHO/O-2 T-5 and CHO/O-2 T-6 cells, the BLM hydrolase activity was determined by HPLC method in comparison with that of the parental cells (Table 6). Both PEPSS clones showed similar levels of the enzyme activity as the parental 
Fig. 5. Repair of PEP-induced DNA cleavage in $\mathrm{CHO}$ (A) and $\mathrm{CHO} / \mathrm{O}-2$ T-6 (B) cells: Centrifugation profiles of DNA.

The time represents incubation period in PEP-free medium.

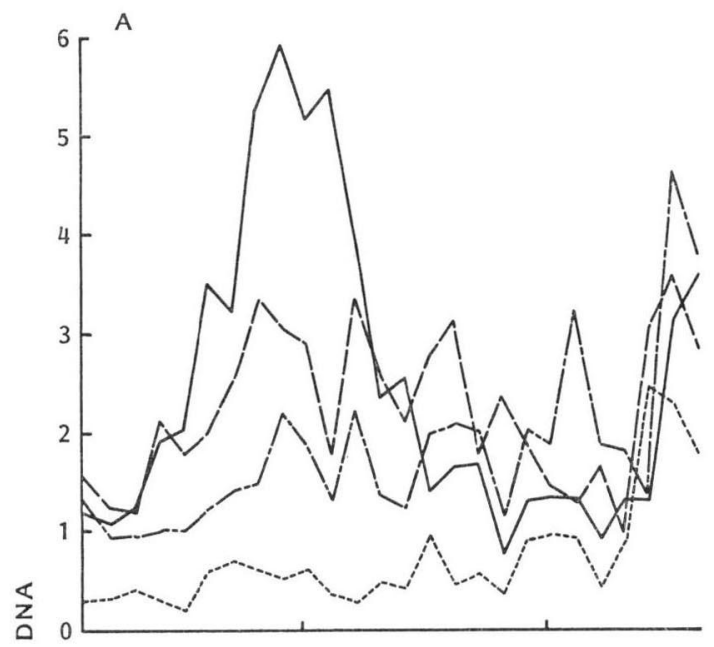$$
\text { ำ }
$$$$
4
$$

$$
\text { B }
$$

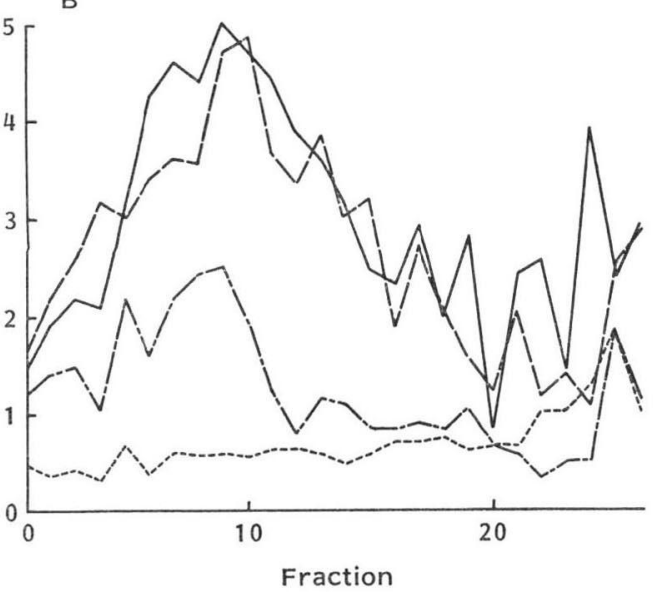

0 minute, --10 minutes,

- - 30 minutes,

$$
\text { ------- Untreated }
$$

Table 7. DNA cleavage induced by PEP in PEPss cell line in comparison with that in the parental cell line: Large size DNA content sedimented to the bottom of centrifugation tubes (fractions $13 \sim$

\begin{tabular}{|c|c|c|c|}
\hline \multirow{2}{*}{\multicolumn{2}{|c|}{$\underset{(\mu \mathrm{g} / \mathrm{ml})}{\mathrm{PEP}}$}} & \multicolumn{2}{|c|}{ Cell line } \\
\hline & & $\mathrm{CHO}$ & $\mathrm{CHO} / \mathrm{O}-2 \mathrm{~T}-6$ \\
\hline & 0 & $67 *(1.00) * *$ & $62 *(1.00) * *$ \\
\hline & 25 & $50(0.74)$ & $18(0.29)$ \\
\hline & 50 & $49(0.73)$ & $13(0.21)$ \\
\hline \multicolumn{4}{|c|}{$\%$ of total DNA. } \\
\hline$* *$ & $\begin{array}{l}\text { The nu } \\
\text { of larg } \\
\text { to that } \\
\text { in the }\end{array}$ & $\begin{array}{l}\text { in the parent } \\
\text { DNA conten } \\
\text { ntrols. The } \\
\text { ments present }\end{array}$ & $\begin{array}{l}\text { represents ratio } \\
\text { PEP-treated cells } \\
\text { lts were obtained } \\
\text { n Fig. } 4 \text {. }\end{array}$ \\
\hline
\end{tabular}
16).

Fig. 6. Repair of PEP-induced DNA breakage in $\mathrm{CHO}(\odot)$ and $\mathrm{CHO} / \mathrm{O}-2 \mathrm{~T}-6(\mathrm{O})$ cells: Large size DNA sedimented to the bottom of tubes.

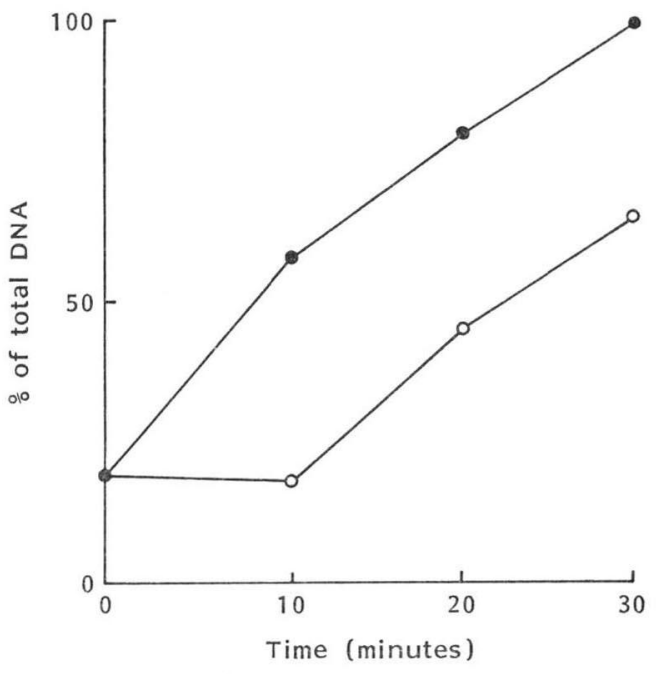

cells, suggesting that the PEPSS is not due to alteration of BLM hydrolase activity.

\section{$\left[{ }^{3} \mathrm{H}\right] \mathrm{PEP}$ Uptake into PEPss Cells}

The uptake of $\left[{ }^{3} \mathrm{H}\right] \mathrm{PEP}$ into $\mathrm{CHO} / \mathrm{O}-2$ T-6 (PEPSs cells) was compared with that into the parental cells. The time course of PEP uptake is illustrated in Fig. 3. $\left[{ }^{3} \mathrm{H}\right] \mathrm{PEP}$ was incorporated into both cell lines in a similar rate, suggesting that the PEPSs is not attributed to increased uptake of PEP into CHO/O-2 T-6 cells.

\section{DNA Strand Scission Induced by PEP in PEPSS Cells}

The fragmentation of cellular DNA by PEP in CHO/O-2 T-6 (PEPSs cells) was comparatively 
studied with that in the parental $\mathrm{CHO}$ cells by alkaline sucrose density gradient centrifugation analysis. The sedimentation is recorded from left to right in Fig. 4. The damaged DNA of small molecular size was found more in CHO/O-2 T-6 cells than in CHO cells. The content of large size DNA, which was sedimented to the bottom of tubes (fractions 13 16), is presented in Table 7. The reduction of large size DNA by the treatment with PEP of 25 or $50 \mu \mathrm{g} / \mathrm{ml}$, was 2.6 or 3.5 fold higher in CHO/O-2 T-6 cells than in $\mathrm{CHO}$ cells. The results suggest that cellular DNA is cleaved more markedly in $\mathrm{CHO} /$ O-2 T-6 cells than in the parental cells.

\section{Repair of DNA Damage induced by PEP in PEPSs Cells}

Repair of DNA strand scission caused by PEP in CHO/O-2 T-6 cells was compared with that in the parental cells by alkaline sucrose density gradient centrifugation analysis. The sedimentation profiles, representing time course of DNA repair, are illustrated in Figs. 5 and 6. The PEP-induced DNA cleavage was repaired progressively after PEP was washed out and the cells were incubated in the PEP-free medium: i.e. the DNA content of small size decreased (Fig. 5), and that of large size increased (Fig. 6). The initial rate of DNA repair of CHO/O-2 T-6 cells was significantly slower than that of the parental cells, suggesting that the former shows lower ability of repairing DNA damage than the latter.

\section{Discussion}

The current studies revealed that V79 celis are more resistant to PEP than CHO cells, and this natural resistance is due to both higher BLM hydrolase levels and lower uptake of PEP. The results are of interest, because in BLM-resistant cells, reported up to present, the resistance is caused by either mechanism, but not by both ${ }^{2 \sim 4)}$. However, the relationship of higher BLM hydrolase activity to lower uptake of PEP remains open to discussion.

The PEPSS of CHO/O-2 T-6 clone is attributed to increased PEP-induced DNA cleavage and decreased repair of the DNA damage. The former may be derived from the latter. However, the detailed mechanism remains to be determined. We are now studying various enzymes involved in breakdown and repair of DNA. The ouabain- and thioguanine-resistance may be not directly linked to PEPSS, because $\mathrm{CHO} / \mathrm{O}-2 \mathrm{~T}-1$ clone, another ouabain- and thioguanine-resistant mutant, is not PEPSS.

The gene responsible for the natural resistance to PEP appears codominantly in the hybrid, which displayed intermediate BLM hydrolase activity between those of the parental cell lines. The results suggest that the expression of BLM hydrolase gene may not be disturbed in the hybrid as in the parental cell lines. The uptake of PEP by the hybrid seemed to be intermediate between those of the parental cell lines. However, the interpretation of the experimental results was difficult (data are not shown). In this connection, the results are in accord with the report ${ }^{11)}$ that macromomycin resistance, which is due to change of membrane transport, is a codominant trait in the hybrids of macromomycin-sensitive and -resistant L5178Y cells.

The PEPSS phenotype is a recessive trait in the hybrids of PEPSS and PEPR cell lines. The mechanism remains to be determined. However, a plausible mechansim of PEPSS is attributed to deficiency of a certain repair enzyme(s). PEPss clones CHO/O-2 T-5 and T-6 showed similar levels of UV sensitivity to $\mathrm{CHO}$ cells (data are not shown). The results suggest that repair mechanism of PEP-induced DNA cleavage or enzyme involved may differ from that of UV-induced DNA damage.

\section{Acknowledgments}

The current works were supported by a Grant-in-Aid for Cancer Research from the Ministry of Education, Science and Culture, Japan. The authors express their deep thanks to Dr. Hamao UmeZawa, Institute of 
Microbial Chemistry, Tokyo, for his generous advice and cooperation.

\section{References}

1) Carter, S. K.; T. Ichikawa, G. Mathé \& H. Umezawa, Ed.: Fundamental and clinical studies of bleomycin. In Gann Monograph on Cancer Research. No. 19 (Japanese Cancer Association). pp. 1 317, University of Tokyo Press, Tokyo, 1976

2) MiYaki, M.; T. Ono, S. Hori \& H. Umezawa: Binding of bleomycin to DNA in bleomycin-sensitive and -resistant rat ascites hepatoma cells. Cancer Res. 35: 2015 2019, 1975

3) Suzuki, H.; T. Nishimura \& N. Tanaka: Drug sensitivity and some characteristics of a bleomycinresistant subline of mouse lymphoblastoma L5178Y cells. J. Antibiotics 34: 1210 1212, 1981

4) AкIYAma, S. \& M. KuwANo: Isolation and preliminary characterization of bleomycin-resistant mutants from Chinese hamster ovary cells. J. Cell. Physiol. 107: 147 153, 1981

5) Suzuki, H.; K. Nagai, H. Yamaki, N. TANaKa \& H. Umezawa: On the mechanism of action of bleomycin: Scission of DNA strands in vitro and in vivo. J. Antibiotics 22: 446 448, 1969

6) Nagai, K.; H. Yamaki, H. Suzuki, N. TAnaKa \& H. Umezawa: The combined effects of bleomycin and sulfhydryl compounds on the thermal denaturation of DNA. Biochim. Biophys. Acta 179: 165 171,1969

7) Takayama, H.; M. Itoh, S. Mizuguchi, H. Abuki, M. Ishibashi \& H. Miyazaki: Absorption, excretion, distribution and metabolism of ${ }^{3} \mathrm{H}$-labelled pepleomycin sulfate. Jpn. J. Antibiotics 31: 895 909, 1978

8) Akiyama, S.; K. Ikezaki, H. Kuramochi, K. Takahashi \& M. Kuwano: Bleomycin-resistant cells contain increased bleomycin-hydrolase activities. Biochem. Biophys. Res. Commun. 101: 55 60, 1981

9) Uehara, Y.; M. Hori \& H. Umezawa: Specificity of transport of bleomycin and cobalt-bleomycin in L5178Y cells. Biochem. Biophys. Res. Commun. 104: 416 421, 1982

10) Sugrmoto, Y.; T. Nishimura, H. Suzuki \& N. Tanaka: Evidence of altered influx of adriamycin into anthracycline-resistant cells. J. Antibiotics 34: 1064 1066, 1981

11) Suzuki, H.; Y. Sugimoto, K. TAnaka, T. Nishimura \& N. Tanaka: Isolation, drug sensitivity, and some biochemical and genetical properties of macromomycin-resistant mouse lymphoblastoma L5178Y cells. J. Antibiotics 37: 602 609, 1984

12) Tanaka, W.: Development of new bleomycins with potential clinical utility. Jpn. J. Antibiotics 30 (Suppl.): S-41 S-48, 1977

13) Suzuki, H.; T. Nishimura \& N. TANAKA: DNA strand scission in vivo and in vitro by auromomycin. Cancer Res. 39: 2787 2791, 1979 